\title{
Pathogenesis of Hemolytic Anemia in Homozygous Hemoglobin C Disease *
}

\author{
Samuel Charache, C. Lockard Conley, David F. Waugh, Richard J. \\ Ugoretz, $\ddagger$ AND J. RICHARd SPURRELl WITH THE TECH NICAL ASSISTANCE OF \\ Esther GAyLe \\ (From the Department of Medicine, The Johns Hopkins University and Hospital, Baltimore, \\ Maryland, and the Department of Biology, Massachusetts Institute of Technology, \\ Boston, Massachusetts)
}

\begin{abstract}
Hemoglobin $\mathbf{C}$ is less soluble than hemoglobin A in red cells, in hemolysates, and in dilute phosphate buffer. Its relative insolubility may be explained by electrostatic interactions between positively charged $\beta 6$-lysyl groups and negatively charged groups on adjacent molecules. Red cells from patients with homozygous hemoglobin $\mathrm{C}(\mathrm{CC})$ disease exhibit aberrant physical properties which suggest that the cells are more rigid than normal erythrocytes. They pass through membrane filters less readily than normal red cells do, and their viscosity is higher than that of normal cells. Differences from normal cells are exaggerated if mean corpuscular hemoglobin concentration (MCHC) is increased, by suspension in hypertonic salt solution. Increased rigidity of $\mathrm{CC}$ cells, by accelerating their fragmentation, may be responsible for formation of microspherocytes. These small dense cells are exceptionally rigid, and probably are even more susceptible to fragmentation and sequestration. Rigidity of CC cells can be attributed to a "precrystalline" state of intracellular hemoglobin, in which crystallization does not occur, although the MCHC exceeds the solubility of hemoglobin in hemolysates.
\end{abstract}

\section{Introduction}

Homozygous hemoglobin $\mathrm{C}$ disease is manifested by mild hemolytic anemia, splenomegaly, and striking morphologic abnormalities of the red cells (1). Most of the red cells have the appear-

\footnotetext{
* Received for publication 19 May 1967 and in revised form 12 July 1967.

These studies were supported by a postdoctoral fellowship, 5-F2-HE-15, 899-02, from the National Heart Institute, Research Grant HE-02799, from the National Heart Institute, a Graduate Training Grant T1-AM5260 , from the National Institute of Arthritis and Metabolic Diseases, Grant GM-05410, from the Division of General Medical Sciences of the U. S. Public Health Service, and a Grant from the Molecular Biology Program of the National Science Foundation.

Purchase and modification of the viscometer was made possible by a special grant from the Medical Foundation, Inc., of Boston, Mass.

¥ Henry Strong Denison Scholar for 1966-67.

Address requests for reprints to Dr. Samuel Charache, The Johns Hopkins Hospital, Baltimore, Md. 21205.
}

ance of target cells or of microspherocytes, but rare erythrocytes contain crystal-like inclusions of hemoglobin $(2,3)$. The number of cells containing inclusions is increased when drying of blood films is retarded (4). Osmotic dehydration, produced by suspension of the cells in $3 \% \mathrm{NaCl}$ solution, results in the formation of crystalloid inclusions in virtually every red cell (5). Inclusions can be produced in red cells of persons with various heterozygous hemoglobin $\mathrm{C}$ disorders, but under comparable conditions, they have not been encountered in red cells containing no hemoglobin C. These observations suggest that the solubility of hemoglobin $\mathrm{C}$ is uniquely low within the red cell $(5,6)$, although its solubility in concentrated phosphate buffers differs little from that of hemoglobin $\mathrm{A}(7,8)$. The purpose of the present study was to investigate the solubility of hemoglobin $\mathrm{C}$ and to determine the effects of the hemoglobin on the physical properties of erythrocytes. 


\section{Methods}

Blood was collected from patients with various hemoglobinopathies and from normal persons, using $1 / 10$ volume of EDTA-NaCl $\left(1.5 \mathrm{~g} \mathrm{Na} \mathrm{ND}_{2}\right.$ EDT plus $7.0 \mathrm{~g}$ $\mathrm{NaCl} / 1000 \mathrm{ml}$ water) as anticoagulant. Studies were completed within $6 \mathrm{hr}$ of blood collection. Red cells were counted electronically (Coulter Couńter, Model A, Coulter Electronics, Hialeah, Fla.) and hemoglobin concentrations were obtained with the use of a commercial hemoglobin standard (Acuglobin, Ortho Diagnostics, Raritan, N. J.). Mean corpuscular hemoglobin concentrations (MCHC) of red cells which had been separated by ultracentrifugation were calculated on the basis of their microhematocrit value (Adams Micro-Hematocrit Centrifuge, Clay-Adams, Inc., New York, N. Y.). All other $\mathrm{MCHC}$ are based on Wintrobe hematocrit value. Hematologic data from patients with hemoglobin $\mathrm{C}$ disease, and from three patients whose blood smears contained many target cells, but whose hemoglobin was normal, are presented in Table I.

Production of intracellular crystals. Two drops of blood were added to $2 \mathrm{ml}$ of salt solution and incubated at various temperatures. The proportion of cells containing crystal-like inclusions was estimated after 1-24 $\mathrm{hr}$ by counting 200 cells in wet preparations. In studies of the effect of osmotic strength on crystal formation, stock solutions of $\mathrm{NaCl}$ containing 2000-3000 mOsm/

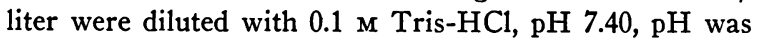
readjusted to 7.4-7.6 with $\mathrm{HCl}$, and osmolarity was again determined (Advanced Instruments 65-31 osmometer, Advanced Instruments, Newton Highlands, Mass.). The effect of propane upon crystal formation was measured in tightly stoppered $40-\mathrm{ml}$ test tubes containing red cells suspended in $2 \mathrm{ml}$ of $3 \% \mathrm{NaCl}$ solution. Individual samples for each time period were flushed at least 10 times with either nitrogen or propane (Bernzomatic Pro- pane Fuel, Bernzomatic Corporation, Rochester, N. Y.), incubated at $37^{\circ} \mathrm{C}$ for $1-5 \mathrm{hr}$ under a positive pressure of $300 \mathrm{~mm} \mathrm{Hg}$, and the proportion of crystal-containing cells was estimated in wet preparations immediately after opening each tube. In some experiments, tubes containing oxygen were used as controls.

Ultracentrifugal separation of red cells. Red cells were separated by centrifugation at $2000 \mathrm{~g}$ for $10 \mathrm{~min}$ and then for $2 \mathrm{hr}$ at an average centrifugal force of $51,000 \mathrm{~g}$ in the SW39L rotor of a Beckman model L preparative ultracentrifuge (Beckman Instruments, Inc., Palo Alto, Calif.). Supernatant plasma and white cells were removed, and the column of packed red cells was sliced into quarters. Each fraction was resuspended in autologous plasma; microhematocrit, hemoglobin content, and red cell count were measured; and the samples were utilized for further studies. In certain experiments, cohorts of radioactively labeled young red cells were required. To obtain these, we injected $5 \mu \mathrm{c}$ of citrate ${ }^{50} \mathrm{Fe}$ intravenously into two patients with homozygous hemoglobin $\mathrm{C}$ disease and into a normal volunteer. Blood samples were obtained at weekly intervals thereafter, subjected to ultracentrifugation, and the fractions obtained were counted in a Picker Spectroscaler III A well counter (Picker X-Ray Corp., White Plains, N. Y.)

Red cell filtration. Measurements of the passage of red cells through membrane filters were carried out by modifications of previously described methods $(9,10)$. Red cell suspensions containing $10-20 \times 10^{3}$ cells $/ \mathrm{mm}^{3}$ were established by mixing $0.01-0.03 \mathrm{ml}$ of whole blood with $10 \mathrm{ml}$ of $0.01 \mathrm{M}$ Tris- $\mathrm{HCl}$ buffered $\mathrm{NaCl}$ solution, $\mathrm{pH} 7.4$ (Tris- $\mathrm{NaCl}$ ), containing 300,350 , or $400 \mathrm{mOsm} /$ liter. Samples of $0.1 \mathrm{ml}$ of suspension were withdrawn before filtration, for determination of red cell concentration.

Filters were obtained from the Millipore Filter Corporation, and were $2.5 \mathrm{~cm}$ in diameter. They were of

TABLE I

Hematologic data of patients with CC disease, compared with those of patients with target cells attributable to other disorders

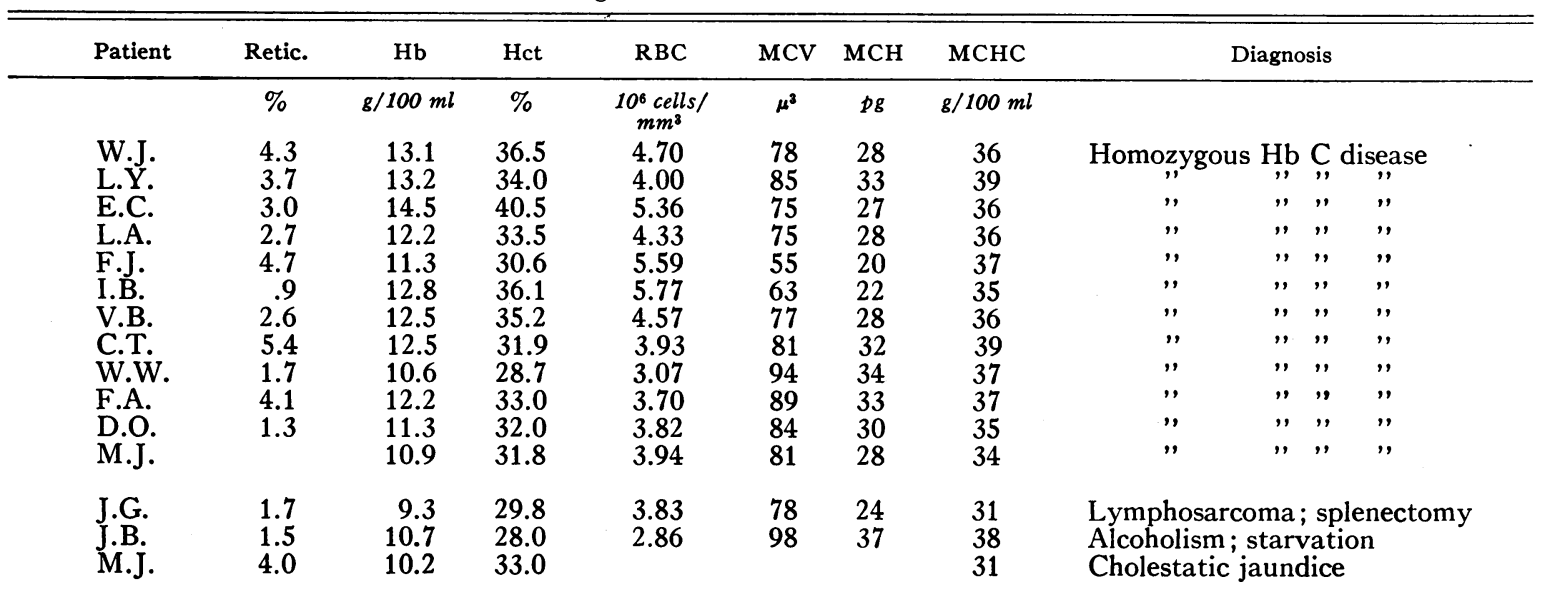

Retic., reticulocyte; Hb, hemoglobin; Hct, hematocrit; RBC, red blood cells; MCV, mean corpuscular volume; $\mathrm{MCHC}$, mean corpuscular hemoglobin concentration. 


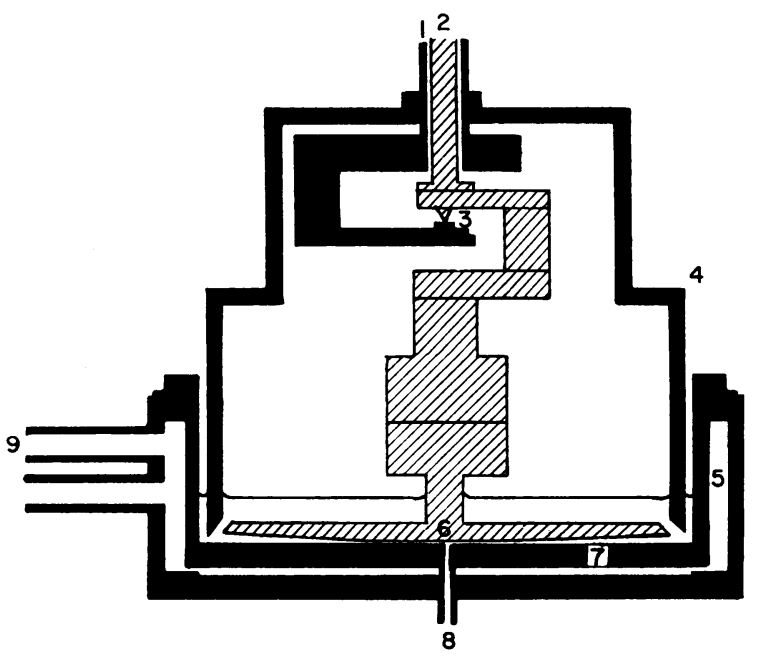

I. To motor

2. To Torsion spring

3. Bearing

4. Guard ring

5. Water jacket

6. Cone

7. Plate

8. Sample inlet

9. Connection to water bath

Fig. 1. Sample cup, cone, and guard Ring of modified Brookfield LVT VISCOMETER.

average pore size $1.2,3,5$, and $8 \mu .^{1}$ The filter support, supplied by the filter manufacturer, was found to retain a significant number of red cells, and was replaced by a Lucite funnel of similar dimensions which contained no sintered glass disk. The filter, although supported only at its periphery, withstood the applied pressure of $2.0 \pm$ $0.5 \mathrm{~cm} \mathrm{Hg}$. The filter funnel (XX10 025 04, Millipore Filter Corp., Bedford, Mass.) contained $10 \mathrm{ml}$ of suspension; the entire sample was filtered, and red cell concentration in the filtrate was measured. Recovery of red cells was expressed as a per cent of the initial concentration.

Normal red cells, suspended in buffered $\mathrm{NaCl}$ solution, did not pass through $1.2 \mu$ pores, but they passed readily through filters of average pore size 3,5 , or $8 \mu$. During filtration, red cells passed through the filter more slowly than did the suspending medium. The rate of red cell filtration was quite variable. The proportion of the initial number of cells which was recovered in the filtrate was less variable, but depended upon the pore size and the concentration and volume of the initial suspension. Increased filtration pressure increased the rate of filtration, but did not significantly affect the proportion of cells recovered. Red cells did not traverse the filter at all if the $\mathrm{pH}$ of an isotonic suspending medium was below 7.2. Detailed analyses of the factors involved in red cell filtration will be published elsewhere (J. R. Spurrell, U. Gessner, and S. Charache, manuscript in preparation).

Viscometry of red cells and hemolysates. Red blood cells, separated from plasma by a brief centrifugation, were suspended in 10 volumes of Tris $-\mathrm{NaCl}$ solution, incubated at room temperature for $30-40 \mathrm{~min}$, and then centrifuged for $1 \mathrm{hr}$ at $8000 \mathrm{~g}$ in a refrigerated centrifuge. Hemolysates, prepared from washed red cells using $\mathrm{CCl}_{4}$ and distilled water, were cleared by centrifugation,

1 RAWP $02500 \quad(1.2 \mu)$; SSWP 02500 (3 $\mu)$; SWWP $02500(5 \mu)$; SCWP $02500(8 \mu)$. concentrated by ultrafiltration and pervaporation through moistened dialysis tubing, and diluted when necessary with Tris- $\mathrm{NaCl}, 300 \mathrm{mOsm} /$ liter. Invariably, a sediment was present in concentrated samples of hemoglobin $\mathrm{C}$, but not in samples of hemoglobin A.

Initially, viscosity determinations were made with an unmodified Brookfield LVT cone-plate viscometer (Brookfield Engineering Laboratories, Inc., Stoughton, Mass.) It became apparent that the viscosity of a given sample determined at a particular time was strongly dependent upon the technique of preceding measurements, in particular, applied shear rates, time between measurements, and temperature. Results obtained during a given sequence of measurements could not be duplicated during a second set of measurements on the same sample.

Surface denaturation at the air-protein interface was considered to be the most important contributor to nonreproducibility, via the surface film which extended from the stationary walls of the sample cup to the shaft of the rotating cone, or to the cone itself. Effects of this presumed surface film were minimized by placing a guard ring between the sample cup and the cone.

The essential modification of the apparatus is shown in Fig. 1. A stainless steel guard ring is mounted on the same shaft as the bearing which supports the cone; this shaft is coupled directly to the motor, while the cone is coupled to it, as usual, by means of a torsion spring. The cone, also constructed of stainless steel, is reduced in thickness to 0.040 inch at the center, so that it can be completely covered by a sample of $6 \mathrm{ml}$ of fluid. The circumference of the shaft of the cone has been reduced by decreasing its diameter to 0.1875 inch.

The effects of the surface film are exerted only in the region between the guard ring and sample cup: with the exception of periods of acceleration or deceleration, the cone, the guard ring and the fluid above the cone move at the same angular velocity. During transient periods of changing velocity, the effect of the surface film is small, 
for its area is large with respect to the circumference of the shaft of the cone at the point of contact.

Certain other modifications of the viscometer have proved useful. An inlet, at the base of the sample cup, permits introduction and withdrawal of samples without dismantling the apparatus. Not shown in Fig. 1 are modifications in the tube which supports the sample cup. Gas ports have been provided, to permit maintenance of a desired atmosphere, and a heating element has been placed above the guard ring. This element maintains the section of the viscometer above the guard ring at the same temperature as that of the sample cup, and prevents condensation of water vapor within the machine. The guard ring is fenestrated, to permit circulation of gas and to facilitate cleaning and removal of the cone. Holes are also provided to give easy access to counterweights in the vicinity of the cone-support bearing.

Measurements were carried out at $37^{\circ} \mathrm{C}$ and at shear rates of $1.15-23.0 \mathrm{sec}^{-1}$. After measurements of viscosity, the microhematocrit value of red cell suspensions, or the hemoglobin content of hemolysates, was measured. If the microhematocrit value did not exceed $97 \%$, the results of the experiment were discarded. Differences in the viscosity of normal and $\mathrm{CC}$ red cells were evaluated by means of the $t$ test. In studies of the viscosity of target cells and microspherocytes which had been separated by ultracentrifugation, it was necessary to use 3-ml samples. Surface denaturation was not detected within the 5-10 min necessary for measurements of these samples.

Solubility of hemoglobin. Solutions used in these studies either were saturated with carbon monoxide or contained a final concentration of $10 \mathrm{mg} / \mathrm{ml}$ of sodium dithionite. Measurements were made at $20-23^{\circ} \mathrm{C}$. Phosphate buffers, $\mathrm{pH} 7.2$, of desired ionic strength, were prepared according to the nomogram of Green (11). In addition, buffers of $2-20 \times$ these concentrations were prepared.
Undialyzed hemolysates were concentrated by ultrafiltration for several days. Concentrated buffer (0.5-0.05 $\mathrm{ml}$ ) was added to $0.5-0.95 \mathrm{ml}$ of hemolysate, to give approximately the desired final ionic strength. If a precipitate formed immediately, more buffer of the desired final ionic strength was added until most, but not all, of the hemoglobin precipitate had dissolved. Samples were centrifuged, and supernatant solutions were decanted and filtered through Whatman No. 1 filter paper, when practical. Hemoglobin concentration in the supernatant fluid was measured as cyanmethemoglobin, after prolonged exposure to Drabkin's solution ( $1 \mathrm{~g} \mathrm{NaHCO}_{3}, 0.05 \mathrm{~g}$ $\mathrm{KCN}, 0.2 \mathrm{~g} \mathrm{~K}_{8} \mathrm{Fe}(\mathrm{CN})_{6}$ /liter $\left.\mathrm{H}_{2} \mathrm{O}\right)$.

Mean corpuscular volume. Red blood cells from two $\mathrm{CC}$ patients and from two normal persons were suspended in filtered ( $0.45 \mu$ HAWP 04700, Millipore Filter Corp. Bedford, Mass.) Tris- $\mathrm{NaCl}$ solutions of known tonicity. Mean corpuscular volume (MCV) was measured electronically (MCV Computer, Coulter Counter Model B, Coulter Electronics, Hialeah, Fla.). In addition, red cells from these individuals were washed three times with the same Tris- $\mathrm{NaCl}$ solutions, suspended in an equal volume of the appropriate solution, and $\mathrm{MCV}$ was calculated from the red count and hematocrit value.

\section{Results}

Formation of inclusions within red cells. When $\mathrm{CC}$ cells were incubated in $3 \% \mathrm{NaCl}$, hemoglobin first aggregated in irregular masses. With time, these aggregates developed a crystal-like appearance. Often two or three hexagonal inclusions formed within a cell, while the remainder of the cell appeared free of hemoglobin (Fig. 2A). Normal red cells rapidly crenated in $3 \% \mathrm{NaCl}$, but $\mathrm{CC}$ cells did not; crystals were never seen in normal cells.

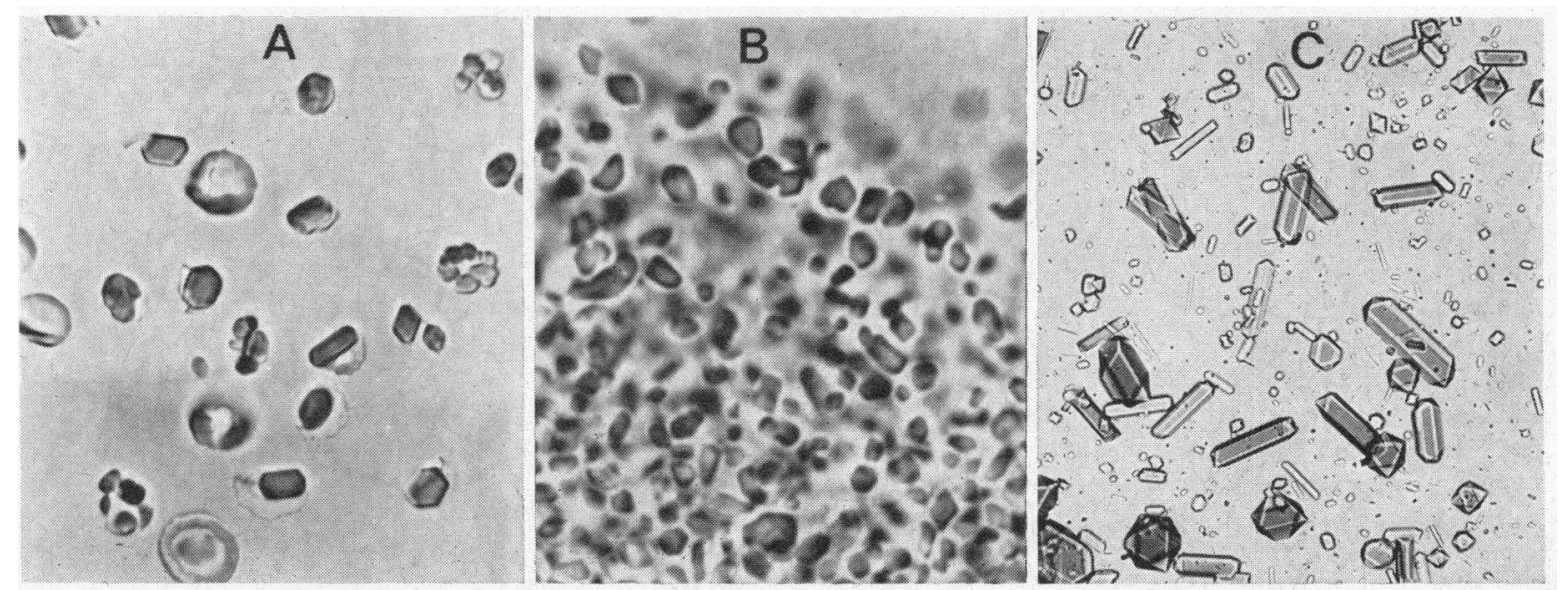

Fig. 2. CRYstals of hemoglobin C. A, Red cells from a CC hemozygote suspended in $3 \% \mathrm{NaCl}$ solution for 6 hr at $37^{\circ} \mathrm{C}(\times 1400) ; \mathrm{B}$, Hemolysate concentrated by ultrafiltration for $36 \mathrm{hr}$ at $4^{\circ} \mathrm{C}(\times 1400)$; C, Hemolysate concentrated for 4 days at $4^{\circ} \mathrm{C}(\times 120)$. 
The rate of crystal formation was temperature dependent. Inclusions appeared within $1 \mathrm{hr}$ at $56^{\circ} \mathrm{C}$, but the cells hemolyzed shortly thereafter. Crystals were formed within $4 \mathrm{hr}$ at $37^{\circ} \mathrm{C}$, but the cells did not lyse, and this temperature was chosen as the standard condition for incubation. Crystal formation was delayed at room temperature, and did not occur within $24 \mathrm{hr}$ at $4^{\circ} \mathrm{C}$. Preincubation at $0^{\circ} \mathrm{C}$ did not alter the rate of crystal formation during subsequent incubation at $37^{\circ} \mathrm{C}$.

The rate of crystallization was not $\mathrm{pH}$ dependent over the range $\mathrm{pH}$ 6-8. Crystals formed somewhat more readily in $\mathrm{NaCl}$ and $\mathrm{KCl}$ solution than in sucrose solution of the same osmolarity (Fig. 3). Crystallization proceeded most rapidly in solutions which contained 900-1100 mOsm/ liter; the $\mathrm{MCHC}$ of $\mathrm{CC}$ cells in these solutions exceeded $48 \mathrm{~g} / 100 \mathrm{ml}$. Crystal formation was inhibited by salt concentrations of $1500 \mathrm{mOsm} /$ liter (0.75 mole/liter) or higher. Crystallization was facilitated by exposure of CC cells to a positive pressure of $300 \mathrm{~mm} \mathrm{Hg}$ of either nitrogen or propane (Fig. 4). Sickling of SS cells was inhibited by propane under these conditions, as previously reported by Murayama (12).

In dried films prepared from CC blood, which had been incubated in $3 \% \mathrm{NaCl}$, microspherocytes appeared to have been replaced by cells containing crystals. To determine whether crystals formed preferentially in microspherocytes, we subjected $\mathrm{CC}$ blood to ultracentrifugation. The uppermost

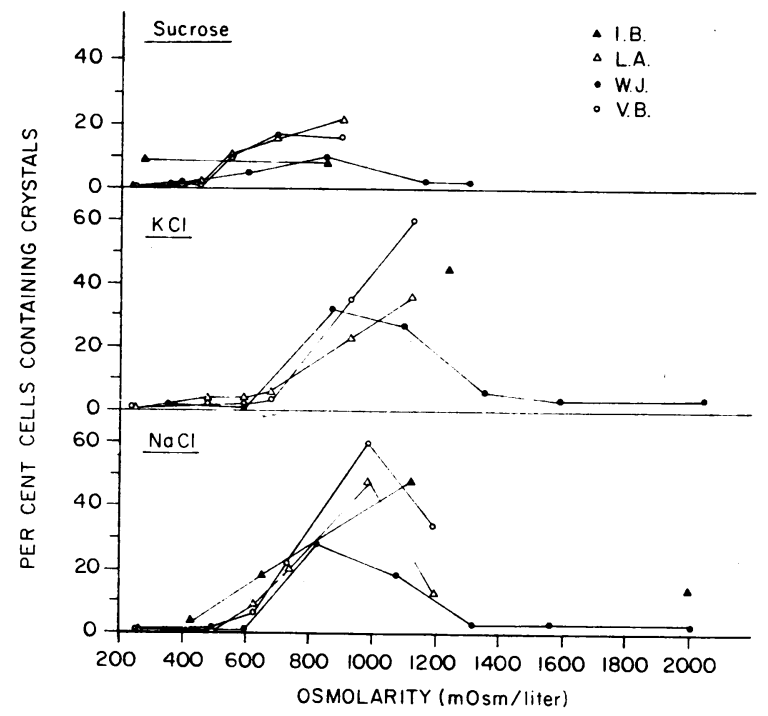

Fig. 3. CoMparison OF EFFECT OF SUCROSE, $\mathrm{KCl}$, AND NACL SOLUTIONS ON FORMation OF CRYSTALS IN CC cELLS.

layer of cells in the centrifuge tube was composed of target cells, while the bottom layer of the red cell column was predominantly microspherocytes (Fig. 5).

As anticipated from their appearance on blood films, microspherocytes were smaller than target cells and their MCHC was higher (Table II). Cells from the bottom of a tube of centrifuged normal red cells were also smaller than cells from the top and their MCHC was higher, but the dif-

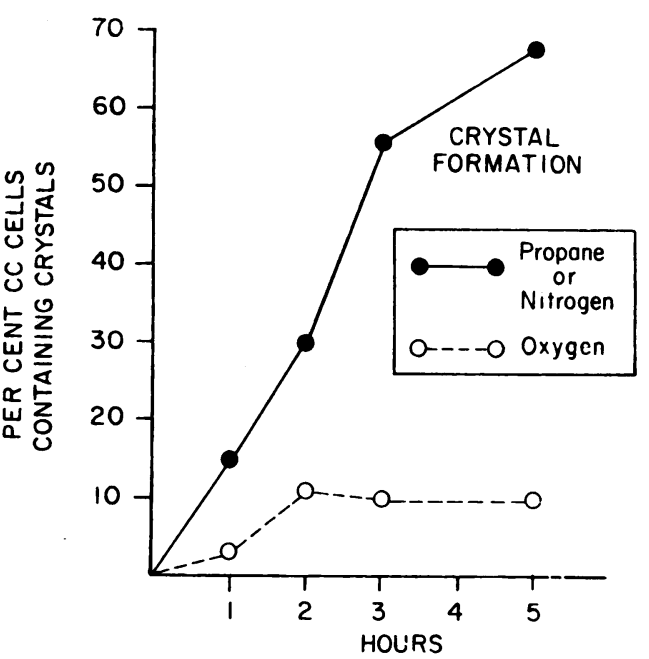

Fig. 4. EFFECT OF PROPANE ON CRYSTAL FORMATION IN CC CELls, COMPARED With its EFfECT on SiCKling of Cells From a patient with sickle cell anemia. Crystal formation was enhanced by either propane or nitrogen, but sickling was inhibited by propane. 


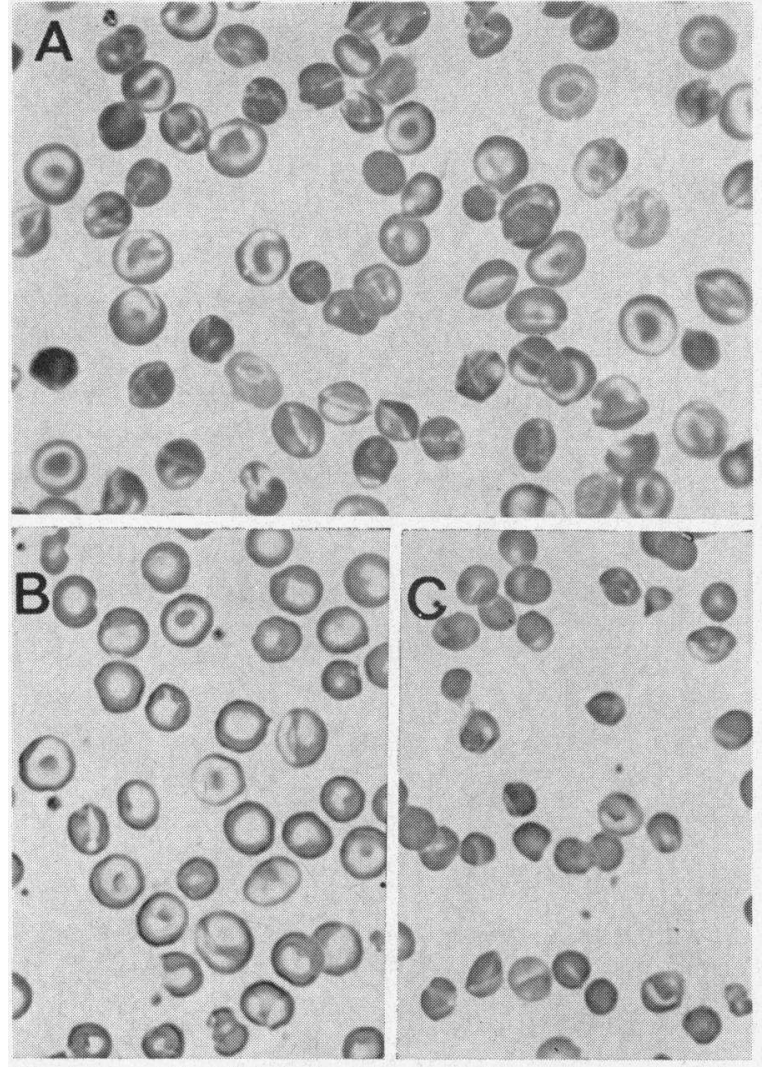

Fig. 5. Blood smear (A) from a patient with CC DISEASE. Target cells (B) and microspherocytes (C) were separated by centrifugation.

ference between top and bottom layers was much less striking than that encountered with $\mathrm{CC}$ cells.

When a cohort of normal red cells is labeled with ${ }^{59} \mathrm{Fe}$ and blood samples are subjected to ul-

TABLE II

Comparison of properties of $A A+C C$ red cells fractionated by ultracentrifugation

\begin{tabular}{|c|c|c|c|c|c|}
\hline Subject & Tube & $\begin{array}{c}\text { Radio- } \\
\text { activity* }\end{array}$ & $\mathrm{MCHC}$ & MCV & Viscosity $\ddagger$ \\
\hline & fraction & $\underset{\text { cells }}{c p m / 10^{\circ}}$ & $\mathrm{g} / 100 \mathrm{ml}$ & $\mu^{8}$ & poise \\
\hline AA 1 & $\begin{array}{l}\text { Top } \\
\text { Bottom }\end{array}$ & $\begin{array}{r}82.2 \\
4.9\end{array}$ & $\begin{array}{l}29.8 \\
34.9\end{array}$ & $\begin{array}{r}116.5 \\
82.0\end{array}$ & $\begin{array}{l}23.5,20.0 \\
20.0,31.0\end{array}$ \\
\hline AA 2 & $\begin{array}{l}\text { Top } \\
\text { Bottom }\end{array}$ & & $\begin{array}{l}30.3 \\
36.9\end{array}$ & $\begin{array}{l}96.5 \\
80.5\end{array}$ & $\begin{array}{l}25.6,29.4 \\
31.0,28.9\end{array}$ \\
\hline CC 1 & $\begin{array}{l}\text { Top } \\
\text { Bottom }\end{array}$ & $\begin{array}{l}98.1 \\
11.4\end{array}$ & $\begin{array}{l}33.3 \\
38.5\end{array}$ & $\begin{array}{l}91.5 \\
76.0\end{array}$ & $\begin{array}{l}48.1,45.0 \\
78.4,90.0\end{array}$ \\
\hline $\operatorname{CC} 2$ & $\begin{array}{l}\text { Top } \\
\text { Bottom }\end{array}$ & & $\begin{array}{l}28.8 \\
42.2\end{array}$ & $\begin{array}{r}117.5 \\
73.8\end{array}$ & \\
\hline $\mathrm{CC} 3$ & $\begin{array}{l}\text { Top } \\
\text { Bottom }\end{array}$ & $\begin{array}{r}78.1 \\
2.9\end{array}$ & $\begin{array}{l}31.4 \\
38.8\end{array}$ & $\begin{array}{l}73.5 \\
63.5\end{array}$ & $\begin{array}{l}36.7 \\
56.3\end{array}$ \\
\hline $\mathrm{CC} 4$ & $\begin{array}{l}\text { Top } \\
\text { Bottom }\end{array}$ & & $\begin{array}{l}36.7 \\
41.6\end{array}$ & $\begin{array}{l}89.0 \\
73.5\end{array}$ & \\
\hline
\end{tabular}

* 1 wk af ter administration of ${ }^{59} \mathrm{Fe}$. $\ddagger$ Shear rate $2.3 \mathrm{sec}^{-1}, 37^{\circ} \mathrm{C}$. tracentrifugation during succeeding weeks, the label initially appears at the top of the red cell column and gradually moves downward as the cells become older $(13,14)$. To determine whether CC cells behaved in a similar fashion, we administered isotope to two patients. Radioactivity was initially localized to the top layer of the centrifuge tube, in patients as in the normal control ( Table II). Over a 6 wk period, radioactivity gradually descended to the middle of the red cell column of each of the CC patients, but remained in the uppermost quarter of that of the control. The $\mathrm{MCHC}$ of the microspherocytes in the bottom layer ranged from $38-41 \mathrm{~g} / 100 \mathrm{ml}$ during that 6 wk period.

Although intraerythrocytic crystals were never noted when unaltered CC blood was suspended in isotonic solution, very rare crystal-containing cells were noted in suspensions of separated microspherocytes. When crystal formation was directly compared in microspherocytes and target cells, the salt concentration required for optimum crystal formation in target cells was higher than that required for crystal formation in microspherocytes (Fig. 6). The MCHC of microspherocytes in 2\% $\mathrm{NaCl}$ was $49 \mathrm{~g} / 100 \mathrm{ml}$, while that of target cells in $3 \% \mathrm{NaCl}$ was $47 \mathrm{~g} / 100 \mathrm{ml}$. After a critical hemoglobin concentration had been achieved within the cell, exposure to solutions of higher salt content inhibited the process of crystal formation.

Solubility of hemoglobin $C$. Formation of crystals within CC cells, which had been dehydrated, suggested that hemoglobin $C$ is less soluble than hemoglobin A. Hemolysates from normal persons and CC patients were concentrated by ultra-

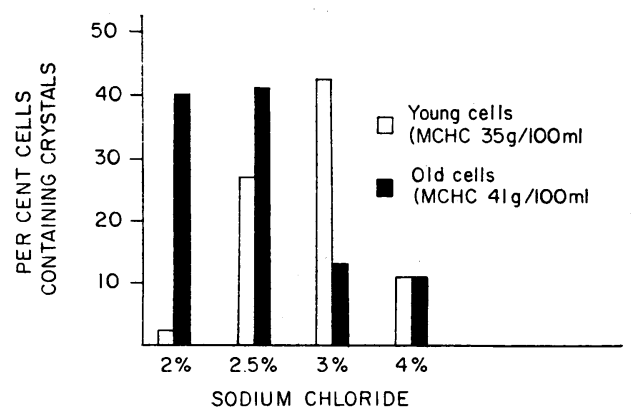

Fig. 6. Effect of NaCl concentration of suspendING MEDIUM ON CRYSTAL FORMATION IN CC cells. A higher salt concentration was required for formation of crystals in young cells than in old cells. MCHC was determined before suspension in $\mathrm{NaCl}$ solution. 
TABLE III

\begin{tabular}{|c|c|c|c|c|}
\hline \multirow{2}{*}{$\begin{array}{c}\text { Ionic } \\
\text { strength }\end{array}$} & \multicolumn{2}{|c|}{ Carboxyhemoglobin } & \multicolumn{2}{|c|}{ Deoxyhemoglobin } \\
\hline & A & $\mathrm{C}$ & A & C \\
\hline & \multicolumn{2}{|c|}{$\mathrm{g} / 100 \mathrm{ml}$} & \multicolumn{2}{|c|}{$\mathrm{g} / 100 \mathrm{ml}$} \\
\hline 4.8 & $\begin{array}{l}4.0 \\
3.5\end{array}$ & $\begin{array}{l}3.6 \\
4.1\end{array}$ & $\begin{array}{l}0.20 \\
0.28\end{array}$ & $\begin{array}{l}0.26 \\
0.31\end{array}$ \\
\hline 3.6 & $\begin{array}{l}8.9 \\
8.6\end{array}$ & $\begin{array}{l}5.6 \\
4.5\end{array}$ & $\begin{array}{l}1.3 \\
1.4\end{array}$ & $\begin{array}{l}2.5 \\
1.9\end{array}$ \\
\hline 2.4 & $>40$ & $>40$ & $\begin{array}{r}11.0 \\
9.3\end{array}$ & $\begin{array}{r}13.4 \\
9.7\end{array}$ \\
\hline 1.2 & $>40$ & $>40$ & $\begin{array}{l}38.6 \\
39.2\end{array}$ & $\begin{array}{l}30.6 \\
28.8\end{array}$ \\
\hline 0.6 & $>40$ & $>40$ & $\begin{array}{l}40.6 \\
42.0\end{array}$ & $\begin{array}{l}34.2 \\
32.4\end{array}$ \\
\hline
\end{tabular}

filtration. Myriads of crystals of hemoglobin C (Fig. 2B) appeared in solutions with a supernatant hemoglobin concentration of $34-36 \mathrm{~g} / 100$ $\mathrm{ml}$; more concentrated hemoglobin $\mathrm{C}$ solutions could not be produced. Crystals did not appear in hemolysates of normal blood at hemoglobin concentrations of $46 \mathrm{~g} / 100 \mathrm{ml}$. Even higher concentrations of hemoglobin A could be achieved. The hemoglobin $\mathrm{C}$ crystals were similar in size and shape to the crystals which formed within red cells (Fig. 2A). Storage of the hemolysates in the cold for several days produced larger, more perfect crystals (Fig. 2C). Neither the crystals within red cells nor these much larger crystals showed detectable birefringence, when examined with a polarizing microscope. Dialysis of hemolysates against $0.001 \mathrm{~m}$ phosphate buffer, $\mathrm{pH}$ 7.2, for 3 days did not prevent crystal formation when the sample was concentrated; after dialysis against 0.001 M phosphate buffer for $1 \mathrm{wk}$, with many changes of the dialyzing fluid, crystals could no longer be produced.

A difference in the solubilities of hemoglobins $A$ and $C$ could be demonstrated in a well-defined system (Table III and Fig. 7). Precipitates of CO-hemoglobin formed only in buffers of high ionic strength; in the latter buffers hemoglobin $\mathrm{C}$ was less soluble than hemoglobin A. Deoxyhemoglobin was less soluble, and precipitates formed in each of the five buffers studied. Hemoglobin C was slightly more soluble than $\mathrm{A}$ in the more concentrated buffers, but the reverse was true in buffers of ionic strength 1.2 and 0.6. It should be noted that the buffer of ionic strength 0.6 contained a total of 0.24 mole of phosphate per liter,

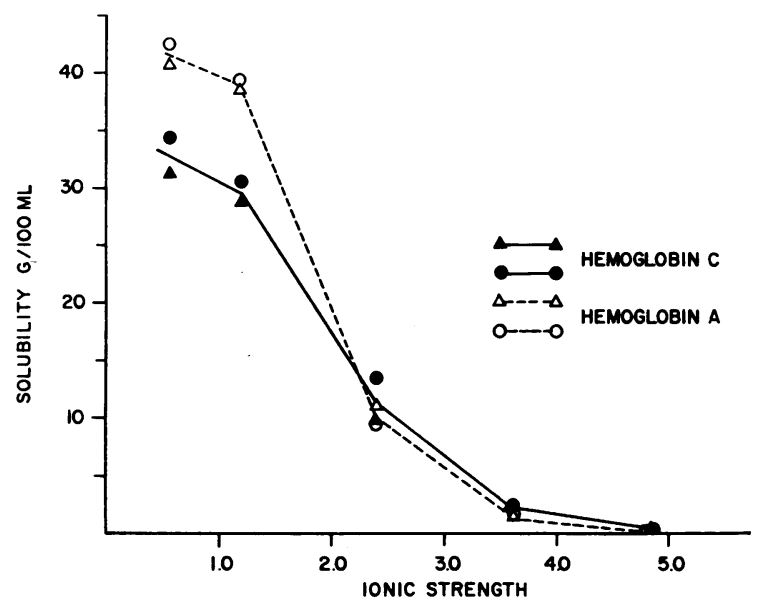

Fig. 7. Solúbility of DEOXYhemoglobin IN PhOSPhate BUFFERS, PH 7.2.

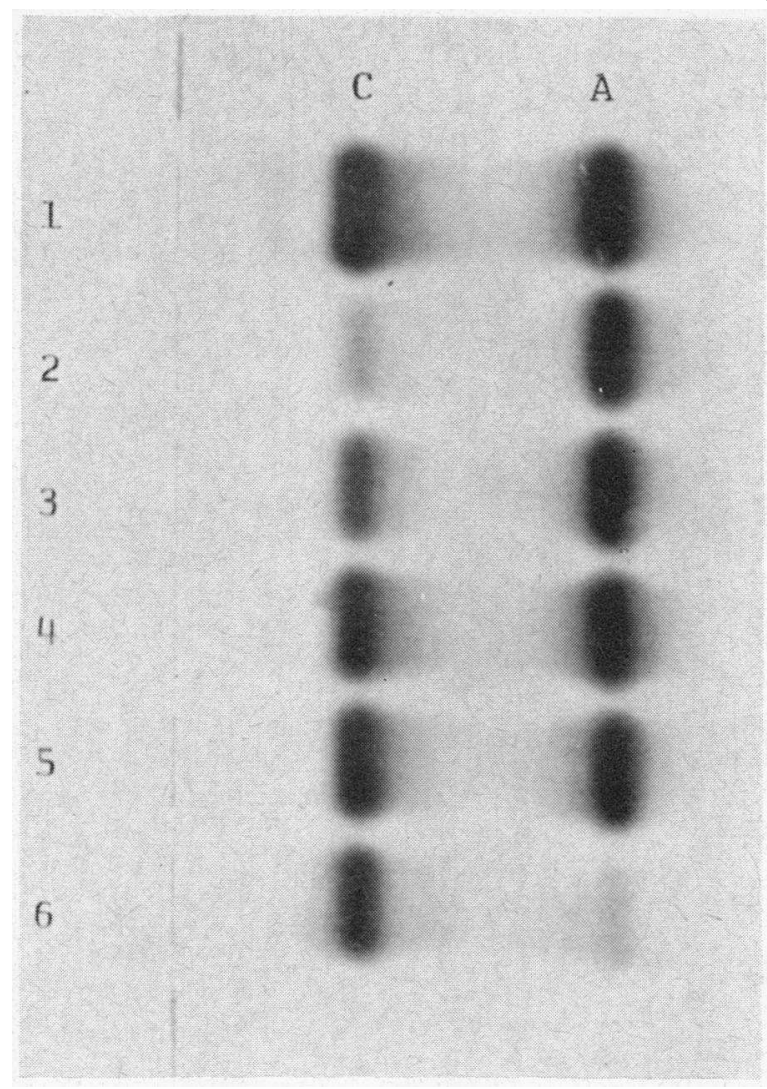

Fig. 8. Starch GEL electrophoresis OF hemolysates PREPARED FROM SUCCESSIVE ALIQUOTS OF MIXTURE OF AA AND CC CELls, AFTER PASSAGe THROUGH A SINGLE $3 \mu$ FILTER. 1, Initial mixture before filtration; 2, first aliquot of filtrate; 3,4 , and 5 , successive aliquots; 6 , cells washed out of the filter after it became clogged. 
and had an osmolarity of 0.5 Osm/liter, compared to the normal serum osmolarity of $0.3 \mathrm{Osm} /$ liter.

Red cell filtration. Equal numbers of $\mathrm{AA}$ and $\mathrm{CC}$ cells were suspended in a large volume of buffered $\mathrm{NaCl}$, which contained $400 \mathrm{mOsm} /$ liter. Successive $10-\mathrm{ml}$ portions of suspension were passed through a single filter until the filter became clogged. The proportion of each type of cell in the filtrate was determined by electrophoresis of the hemoglobin.

The first sample of filtrate contained predominantly hemoglobin A (Fig. 8). The next sample contained an increased proportion of hemoglobin $\mathrm{C}$ and the final samples contained equal proportions of the two hemoglobins. The filter was reversed and most of the cells which remained within the filter were washed out; they were predominantly CC cells.

The relation between time and recovery of red cells was studied by analyzing filtration of a single $10 \mathrm{ml}$ sample as a series of aliquots. Fig. 9 depicts results for a variety of cell types, each analyzed separately. All cells were suspended in buffered $\mathrm{NaCl}$ solution containing 300 or $400 \mathrm{mOsm} /$ liter. CC cells appeared in the filtrate much later than did normal cells and their recovery was smaller. Cells from persons with heterozygous hemoglobin $\mathrm{C}$ disorders appeared more slowly than normal cells, but more rapidly than $\mathrm{CC}$ cells; their difference from normal was most marked in the hypertonic medium.

Comparisons of a variety of suspending media,

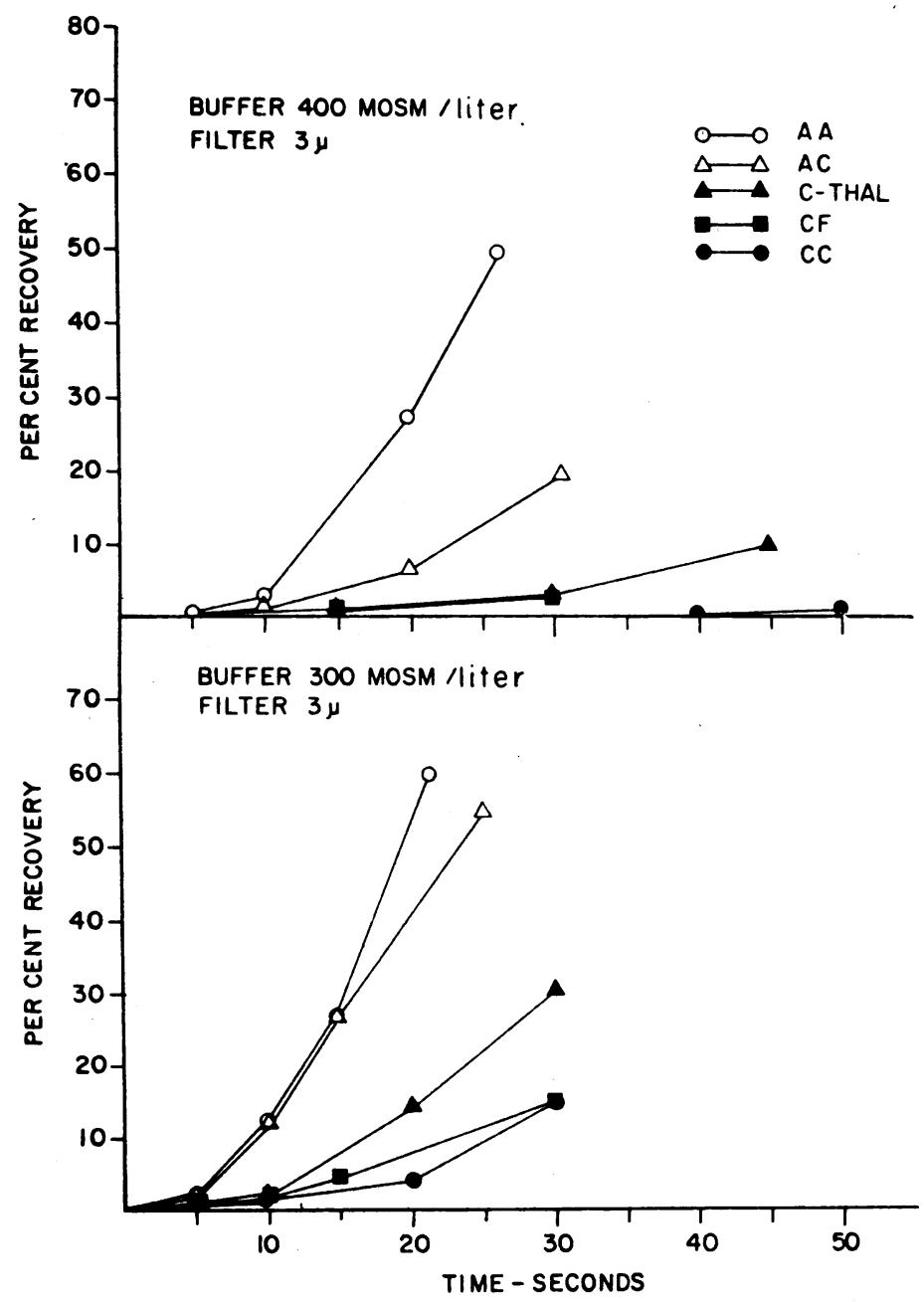

Fig. 9. Recovery of NORMAL RED CELLS AND OF RED CELLS CONTAINiNG HEMOGLOBIN C AFTER FILTRATION. 


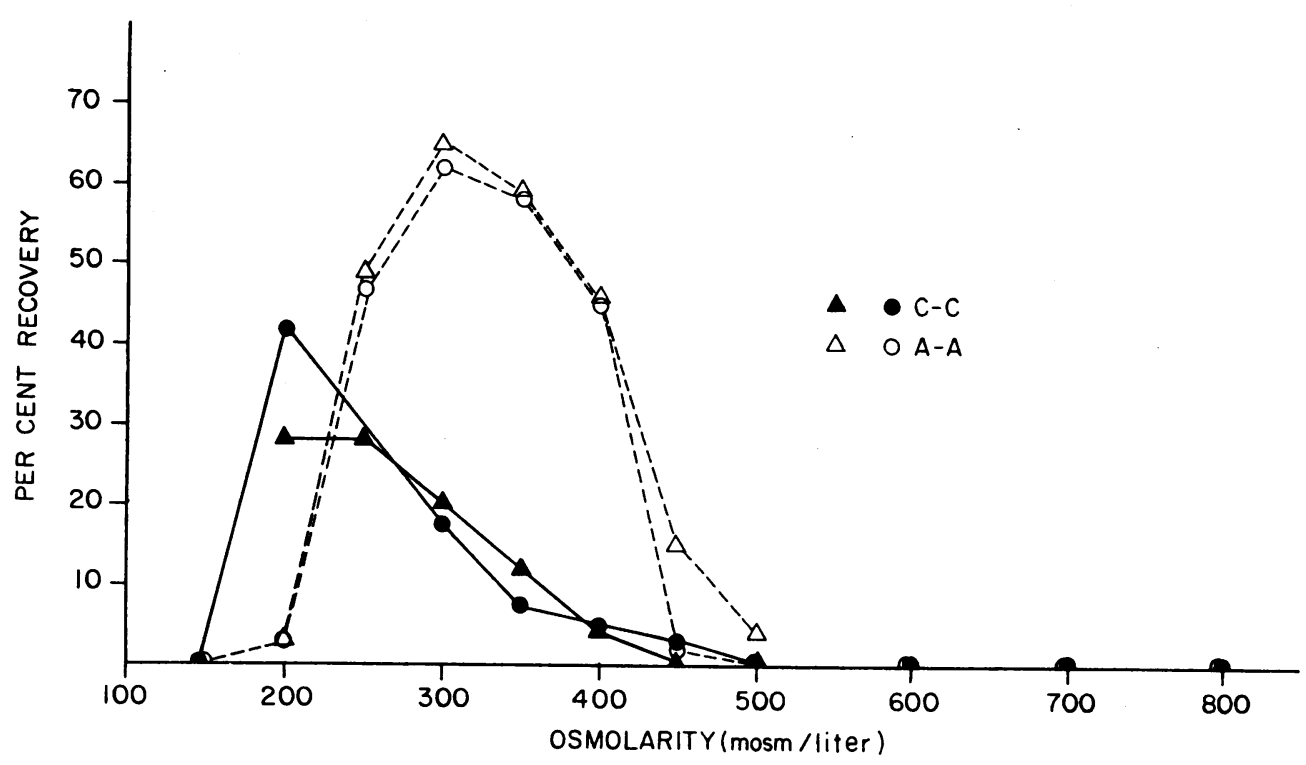

Fig. 10. EFFECT OF OSMOLARITY OF THE SUSPENDING MEDIUM ON RECOVERY OF AA AND CC RED CELLS AFTER FILTRATION THROUgh A $3 \mu$ FILTER.

using 10-ml samples, indicated that there was no tonicity at which CC cells filtered as readily as AA cells (Fig. 10). Recovery of AA cells was greatest when they were suspended in solutions containing $300 \mathrm{mOsm} /$ liter, while recovery of CC cells was optimal in more dilute suspending media. If tonicity was increased or decreased, filtration became progressively slower and eventually the filter clogged, suggesting that the cells could no longer enter the pores of the filter. It should be noted that discrimination between $\mathrm{AA}$ and $\mathrm{CC}$ cells was best with filters of average pore size 3 or $5 \mu$, an average pore size less than the normal red cell diameter.
Although recovery of AA cells decreased before that of CC cells as tonicity was decreased, the reverse was true if tonicity was increased. $\mathrm{CC}$ cells became nonfilterable at $400 \mathrm{mOsm} /$ liter, and AA cells did so at $500 \mathrm{mOsm} /$ liter. The $\mathrm{MCHC}$ of the two cell types became approximately equal when they were suspended in these media (Table IV) ; neither type of cell contained visible crystals.

In general, impairment of filtration was related to the proportion of hemoglobin $\mathrm{C}$ in the hemolysate, and also to the number of target cells seen on blood smears. Impaired filtration was also found in blood samples from patients with a variety of other hematologic disorders (Table V). Some

TABLE IV

Comparison of $\mathrm{AA}$ and $\mathrm{CC}$ red cells in $\mathrm{NaCl}$ solution, $\mathrm{pH} 7.4$

\begin{tabular}{|c|c|c|c|c|c|c|}
\hline & \multirow[b]{2}{*}{ Osmolarity } & \multirow[b]{2}{*}{$\mathrm{MCHC}$} & \multicolumn{2}{|c|}{ Filtration* } & \multicolumn{2}{|c|}{ RBC viscosity $\ddagger$} \\
\hline & & & $\begin{array}{l}\text { No. of } \\
\text { patients }\end{array}$ & $\begin{array}{c}\% \text { recovery } \\
\text { mean } \pm 2 \mathrm{SE}\end{array}$ & $\begin{array}{l}\text { No. of } \\
\text { patients }\end{array}$ & $\begin{array}{c}\text { Centipoise } \\
\text { mean } \pm 2 \mathrm{SE}\end{array}$ \\
\hline AA Normal & $\begin{array}{c}\text { mOsm/liter } \\
300 \\
400 \\
500\end{array}$ & $\begin{array}{c}\mathrm{g} / 100 \mathrm{ml} \\
32 \\
37 \\
39\end{array}$ & $\begin{array}{l}8 \\
8 \\
2\end{array}$ & $\begin{array}{c}53 \pm 5 \\
40 \pm 3 \\
1\end{array}$ & $\begin{array}{l}7 \\
5\end{array}$ & $\begin{array}{l}213 \pm 62 \\
248 \pm 82\end{array}$ \\
\hline AA Target cells & $\begin{array}{l}300 \\
400\end{array}$ & 32 & $\begin{array}{l}3 \\
3\end{array}$ & $\begin{array}{r}26 \\
7\end{array}$ & $\begin{array}{l}2 \\
2\end{array}$ & $\begin{array}{l}135 \\
167\end{array}$ \\
\hline $\mathrm{CC}$ & $\begin{array}{l}300 \\
400 \\
500\end{array}$ & $\begin{array}{l}35 \\
40 \\
41\end{array}$ & $\begin{array}{l}5 \\
5 \\
2\end{array}$ & $\begin{array}{c}17 \pm 15 \\
2 \pm 0 \\
0\end{array}$ & $\begin{array}{l}4 \\
4\end{array}$ & $\begin{array}{l}391 \pm 21 \\
561 \pm 36\end{array}$ \\
\hline
\end{tabular}

* $3 \mu$ filter.

$\ddagger$ Shear rate $2.3 \sec ^{-1}, 37^{\circ} \mathrm{C}$. 
TABLE V

Red cell filtration and viscosity in hematologic disorders

\begin{tabular}{|c|c|c|c|c|c|c|}
\hline \multirow[b]{2}{*}{ Disorder } & \multirow[b]{2}{*}{$\begin{array}{c}\text { No. of } \\
\text { patients }\end{array}$} & \multicolumn{3}{|c|}{$\begin{array}{l}\text { Mean recovery of } \\
\text { filtered cells }\end{array}$} & \multicolumn{2}{|c|}{$\begin{array}{l}\text { Viscosity of packed } \\
\text { red cells* }\end{array}$} \\
\hline & & $\begin{array}{c}300 \\
\text { mOsm/ } \\
\text { liter }\end{array}$ & $\underset{\substack{350 \mathrm{~mm} / \\
\text { liter }}}{350}$ & 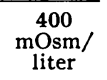 & $\begin{array}{c}300 \\
\text { mOsm/ } \\
\text { liter }\end{array}$ & $\begin{array}{c}400 \\
\text { mosm/ } \\
\text { liter }\end{array}$ \\
\hline & & & $\%$ & & \multicolumn{2}{|c|}{ centipoise } \\
\hline Normal & 7 & 53 & 53 & 40 & 213 & 248 \\
\hline $\begin{array}{l}\text { Hemoglobinopathies } \\
\text { C-C } \\
\text { C-Thal } \\
\text { C-F } \\
\text { A-C } \\
\text { A-F } \\
\text { S-S } \ddagger \\
\text { A-S }\end{array}$ & $\begin{array}{l}5 \\
1 \\
1 \\
4 \\
2 \\
1 \\
1\end{array}$ & $\begin{array}{l}17 \\
30 \\
13 \\
63 \\
45 \\
28 \\
52\end{array}$ & $\begin{array}{r}7 \\
19 \\
9 \\
51 \\
36 \\
13 \\
50\end{array}$ & $\begin{array}{r}2 \\
4 \\
3 \\
28 \\
19 \\
6 \\
33\end{array}$ & $\begin{array}{l}391 \\
185 \\
121 \\
119\end{array}$ & $\begin{array}{l}561 \\
204 \\
259 \\
144 \\
247\end{array}$ \\
\hline $\begin{array}{l}\text { Thalassemia minor } \\
\text { Hereditary spherocytosis§ } \\
\text { Schizocytes } \| \\
\text { Target cells }(2+) \\
(4+)\end{array}$ & $\begin{array}{l}2 \\
1 \\
2 \\
2 \\
3\end{array}$ & $\begin{array}{r}49 \\
0 \\
12 \\
47 \\
26\end{array}$ & $\begin{array}{l}33 \\
16 \\
39 \\
36 \\
19\end{array}$ & $\begin{array}{r}22 \\
16 \\
47 \\
22 \\
7\end{array}$ & 135 & 236 \\
\hline
\end{tabular}

* Shear rate $2.3 \mathrm{sec}^{-1}, 37^{\circ} \mathrm{C}$.

† Oxygenated blood.

$\S$ Before splenectomy.

II After cardiac surgery.

types of red cells showed no change in filterability with altered tonicity of the suspending medium, and a few showed improved filtration after suspension in hypertonic solution. The only samples which resembled CC cells were those which con-

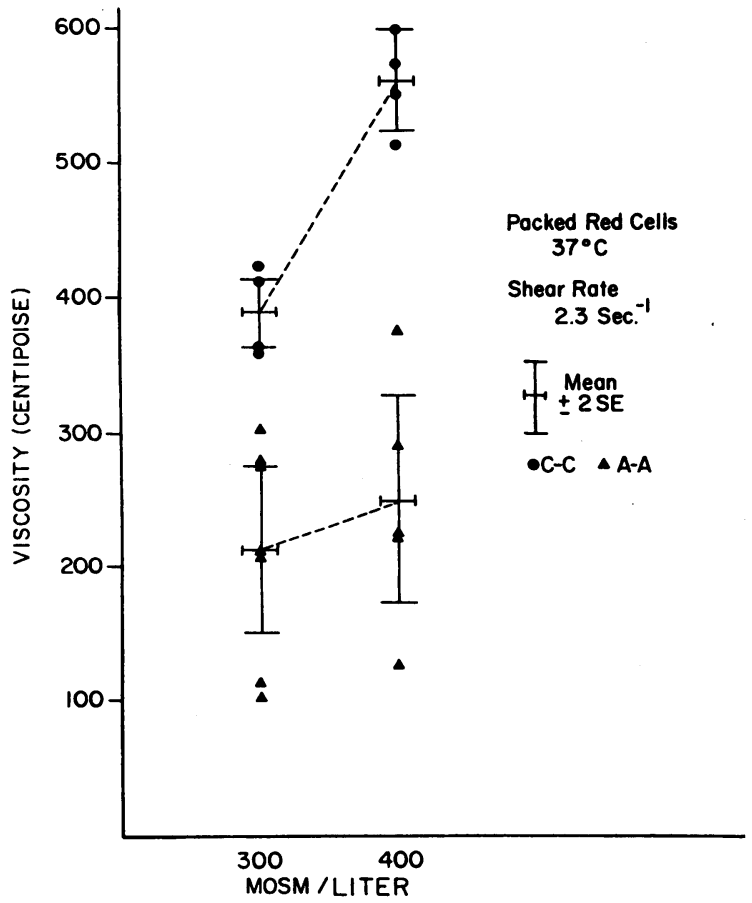

Fig. 11. Viscosity of PaCked AA and CC cells. tained appreciable numbers of target cells. Filtration of blood samples from three patients whose smears contained many target cells, but whose hemoglobin type was normal, yielded results which were indistinguishable from those obtained with $\mathrm{CC}$ cells (Table V). Clinical characteristics of these patients are included in Table I; each appeared to have hemolytic anemia. These patients are referred to again in the results of studies of viscosity of packed red cells; their red cells did not form crystals when suspended in $3 \% \mathrm{NaCl}$.

$V$ iscosity of packed red cells. Packed normal red cells, with a microhematocrit value in excess of $97 \%$, behaved as a non-Newtonian fluid. Viscosity varied from about 100 centipoise (cp) at a shear rate of $11.5 \mathrm{sec}^{-1}$ to about $200 \mathrm{cp}$ at $1.15 \mathrm{sec}^{-1}$ (Table IV). Viscosity of normal red cells appeared to be increased somewhat after the cells had been suspended in buffered saline containing $\mathbf{4 0 0}$ $\mathrm{mOsm} /$ liter, but that change was not statistically significant $(P=0.3)$. CC cells were more viscous than normal cells when suspended in isotonic plasma, and much more viscous in solutions containing $400 \mathrm{mOsm} /$ liter; these differences between $\mathrm{AA}$ and $\mathrm{CC}$ cells were statistically significant $(P<0.01$, Fig. 11). In solutions containing $500 \mathrm{mOsm} /$ liter, $\mathrm{CC}$ cells were about four times as viscous as AA cells. 
$\mathrm{AA}$ and $\mathrm{CC}$ cells were ultracentrifuged from EDTA plasma, and the viscosity of old and young cells was compared (Table II). Although normal cells from the bottom of the red cell column did not differ from top layer cells, CC microspherocytes from the bottom layer were definitely more viscous than target cells from the top of the tube. Red cells from a patient with hereditary spherocytosis (HS) before splenectomy, oxygenated red cells from a patient with sickle cell anemia, target cells from persons with hereditary persistence of fetal hemoglobin and from the three patients whose smears contained many target cells, but whose hemoglobin was normal, all had normal viscosity (Table VI).

$V$ iscosity of hemolysates. Hemolysates prepared from $\mathrm{AA}$ and $\mathrm{CC}$ blood were non-Newtonian fluids; their viscosities did not differ at hemoglobin concentrations below the MCHC of normal red cells (Fig. 12, $35 \mathrm{~g} \mathrm{Hg} / 100 \mathrm{ml}$ ). Measurements of hemolysates with concentrations above $35 \mathrm{~g} / 100 \mathrm{ml}$ appeared to show a difference between hemoglobins A and C. These selected data yielded straight lines when plotted according to:

$$
\ln \frac{\eta}{\eta_{0}}=[\eta] C
$$

where $\eta / \eta_{0}$ is relative viscosity, $[\eta]$ is intrinsic viscosity, and $C$ is concentration in $\mathrm{g} / 100 \mathrm{ml}$ (15). Covariance analysis (16) indicated that there was a significant difference between the two types of hemolysate, for their elevations differed at a confidence level of $<1 \%$. Measurements of CC hemolysates at higher hemoglobin concentrations could not be carried out, because of crystallization of hemoglobin C.

TABLE VI

Comparison of calculated volume per hemoglobin molecule with viscosity of packed red blood cells

\begin{tabular}{lccc}
\hline \hline Cell type & MCHC & $\begin{array}{l}\text { Volume } \\
\text { molecule }\end{array}$ & Viscosity \\
\hline & $g / 100 m l$ & $A^{3} \times 10^{5}$ & poise* \\
Normal & 32 & 3.32 & 2.1 \\
Dehydrated normal & 37 & 2.86 & 2.5 \\
Spherocyte (HS) & 37 & 2.86 & Approx. 300 (25) \\
Sickled cell & 34 & 3.10 & $\mathbf{8 . 4}$ \\
CC microspherocyte & 39 & 2.71 &
\end{tabular}

Crystallographic data suggest that the dimensions of the hemoglobin molecule are $64 \times 55 \times 50 \mathrm{~A}(53)$. If the molecule were a rectangular prism it would occlude a volume of $1.76 \times 10^{5} \mathrm{~A}^{8}$; if it were a freel

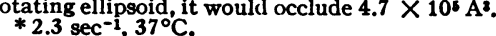

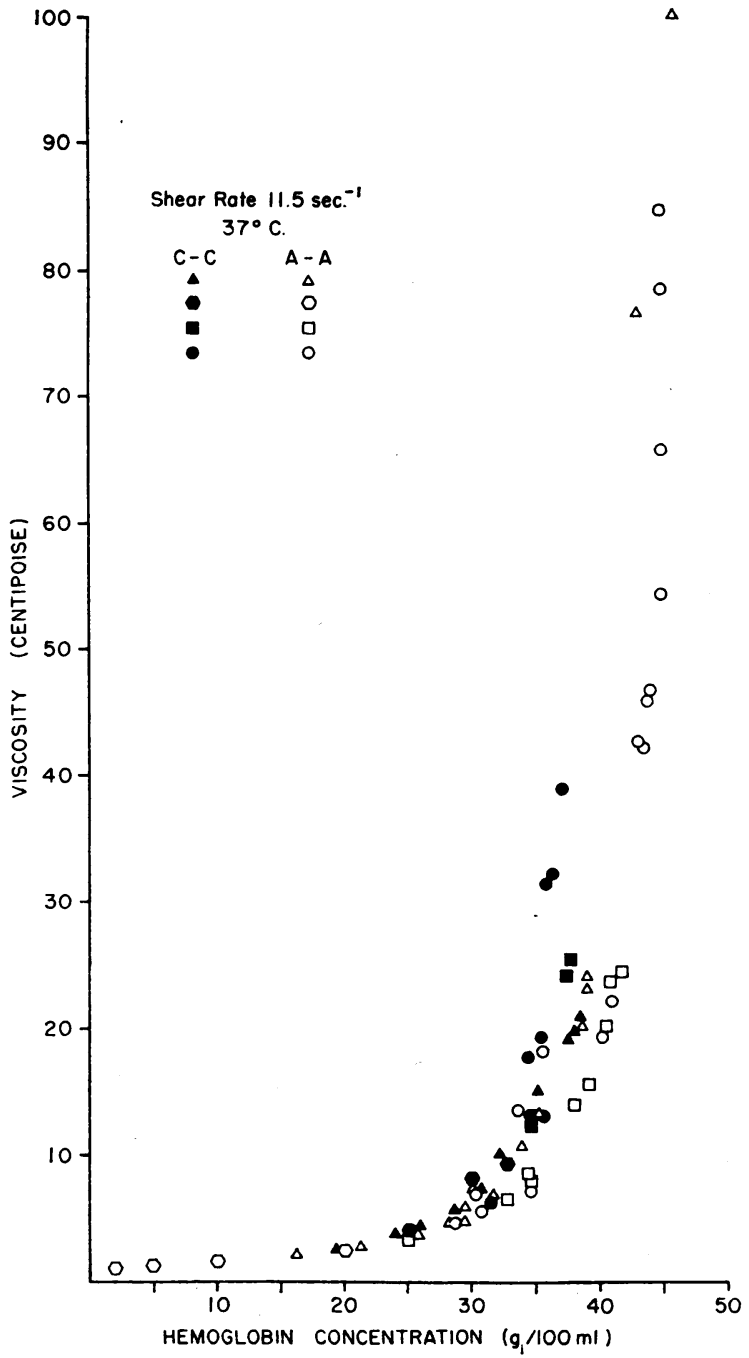

Fig. 12. Viscosity OF HeMOLYSATES PREPAREd FROM AA AND CC CELLS.

Mean corpuscular volume. $\mathrm{CC}$ cells exhibited less pronounced changes in MCV, after suspension in hyper- or hypotonic solutions, than normal cells did (Fig. 13). Relative volumes of AA and CC cells were compared with relative tonicity of the suspending media with the use of :

$$
\frac{V_{t}}{V_{o}}=k\left[\frac{1}{T}-1\right]+1 \text {, }
$$

where $V_{t}$ is $\mathrm{MCV}$ in a solution containing $t \mathrm{mOsm} /$ liter, $V_{o}$ is $\mathrm{MCV}$ in an isotonic reference solution ( $306 \mathrm{mOsm} /$ liter) ; and $T$ is $t / 306$. The constant $k$ reflects the deviation of the behavior of red cells from that of perfect osmometers (17); it can be evaluated from the regression coefficient of $V_{t} / V_{o}$ 

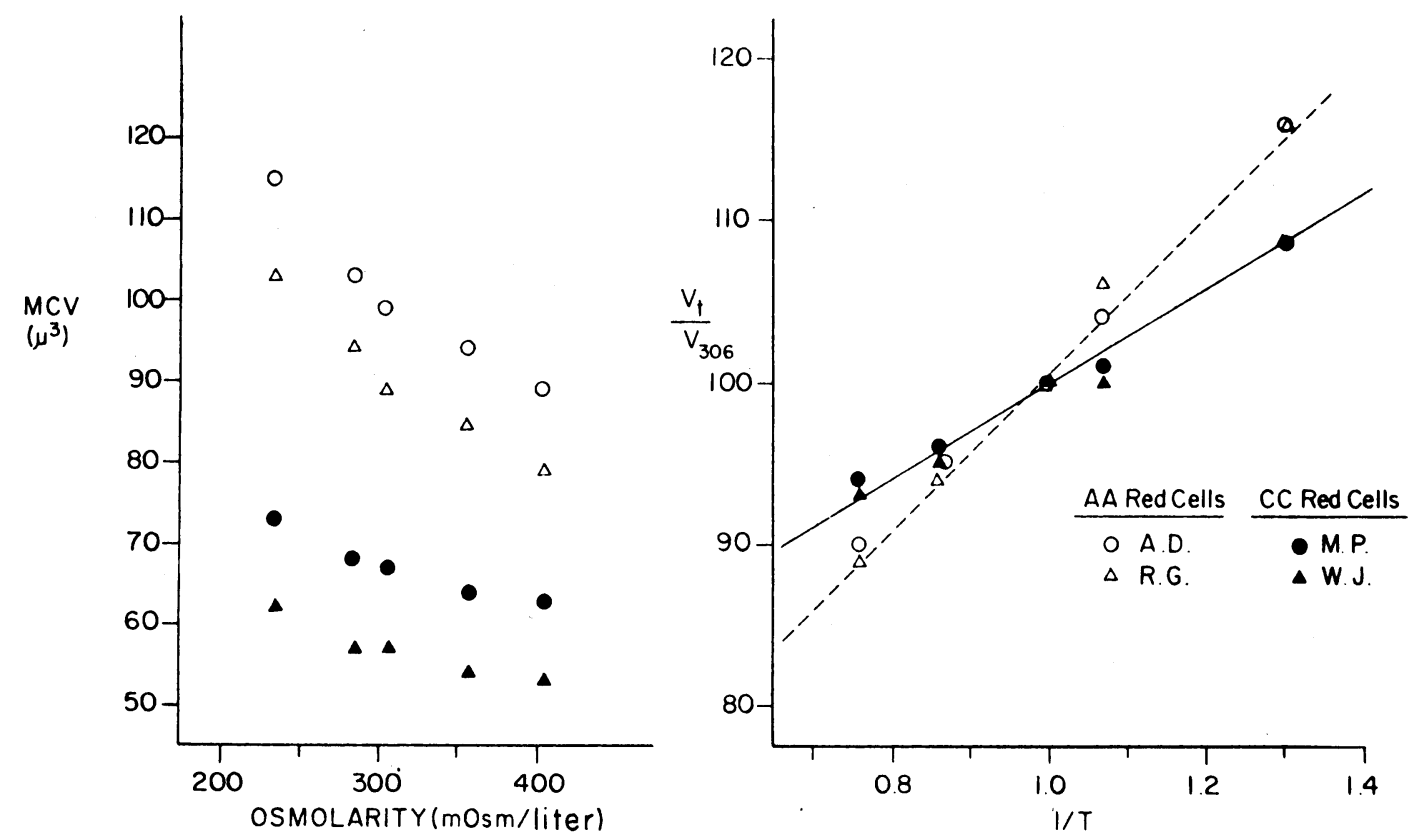

Fig. 13. EFFeCt of tonicity on volume of AA and CC cells. Left: MCV of red cells suspended in Tris- $\mathrm{NaCl}$ of various osmolarities. Right: Relative volume as a function of relative tonicity; the slope of the A-A line is 0.49 , while that of the C-C line is $0.29 . \mathrm{V}_{t}, \mathrm{MCV}$ in solution of tonicity $t ; V_{300}$, $\mathrm{MCV}$ in reference solution containing $306 \mathrm{mOsm} / \mathrm{liter} ; T,(\mathrm{mOsm} /$ liter in solution of tonicity $t) /(306$ $\mathrm{mOsm} / \mathrm{liter}$ ).

on $1 / T$. The regression coefficients for $\mathrm{AA}$ and $\mathrm{CC}$ cells, computed from electronically calculated $\mathrm{MCV}$, differed significantly $\left(k_{A}=0.49, k_{C}=\right.$ $0.29, P<1 \%)$. Very similar results were obtained when MCV were calculated from hematocrit value and red cell count.

\section{Discussion}

Crystals of hemoglobin $\mathrm{C}$ appeared in hemolysates when the hemoglobin concentration exceeded $35 \mathrm{~g} / 100 \mathrm{ml}$; they were not seen in red cells until the $\mathrm{MCHC}$ exceeded $45 \mathrm{~g} / 100 \mathrm{ml}$. Either the physical or the chemical environment of the interior of the red cell prevented intracellular crystallization until this very high hemoglobin concentration was exceeded. An increase in the tendency of hemoglobin to crystallize after it is removed from the interior of the red cell has been described for other species (18), and attributed to the mode of packing of hemoglobin within the cell.

Although hemoglobin $\mathrm{C}$ formed crystals readily when red cells were suspended in $3 \% \mathrm{NaCl}$ solution, hemoglobin A did not. This difference might reflect a difference in solubility, or it might reflect a difference in the time required for precipitation, or for crystallization per se. The last of these hypotheses is improbable, for amorphous precipitates did not form in AA hemolysates at very high hemoglobin concentrations. The second possibility cannot be eliminated, but neither crystals nor precipitates formed in AA hemolysates after ultrafiltration for periods as long as 1 wk.

In contrast to its behavior in concentrated salt solution $(7,8)$, hemoglobin $C$ is less soluble than hemoglobin $\mathrm{A}$ in phosphate buffers of low ionic strength. The difference in solubility of the two hemoglobins is not great, but extrapolation of the solubility curves to lower, physiologic, ionic strengths suggests that greater differences would be encountered if measurements could be made under such conditions.

Both hemoglobins $\mathrm{A}$ and $\mathrm{C}$ are less soluble when deoxygenated than when exposed to carbon monoxide. This difference in solubility of forms of hemoglobin A has been known for many years (19), and similar findings for hemoglobin $C$ have been reported by Huisman et al. (7). Decreased 
solubility of deoxygenated hemoglobin $\mathrm{C}$ was reflected in studies of crystal formation, where red cells deoxygenated by incubation under nitrogen formed many more crystals than those incubated under oxygen. Even normal red cells develop crystals if they are suspended in a deoxygenated hypertonic solution and then allowed to dry slowly between slide and cover slip $(4,20)$. Deoxygenation may play some role in the pathogenesis of CC disease, but that role is probably of little importance, for oxygenated CC cells exhibited strikingly abnormal physical properties.

These abnormal properties were demonstrated by measurements of filtration through membrane filters and by measurements of the viscosity of packed red cells. Both types of measurement are thought to reflect primarily the plasticity of cells $(9,10,21-23)$, but cell size and shape, as well as membrane smoothness, stickiness, and charge, cannot be disregarded.

Preliminary analyses of the process of membrane filtration suggest that some types of cells may be completely nonfilterable, while others traverse the channels of the filter more or less slowly than normal cells do. To a first approximation, in a filter of average pore size of $3 \mu, 83 \%$ of the surface is composed of pores (24); if the unobstructed surface has a radius of $1 \mathrm{~cm}$, there are $4 \times 10^{7}$ pores available. This is to be compared with the approximately $10^{8}$ red cells present in $10 \mathrm{ml}$ of suspension. Although there are slightly more red cells than pores on the filter surface, there are probably many more channels within the filter. Electron micrographs of carbon replicas of the surfaces of membrane fitlers suggest that they are composed of a mesh of cellulose ester fibers, and that their internal structure is a branching interconnected network of channels rather than an array of parallel independent tubes ( $T$. E. Willmarth, personal communication). The filters used in these experiments were $150 \pm 10 \mu$ thick, at least 15 times the red cell diameter, and it is probable that there are at least 15 bifurcations in any given path through the filter, yielding a total number of potential channels, at least equal to the total number of red cells used in $10 \mathrm{ml}$ of suspension.

If the number of channels equals or exceeds the number of cells, recovery $(R)$ of any given type of cell can be described by a function of the type:

$$
R=1-T_{c} / T_{m}-Q,
$$

where $T_{c}$ is the time for cells to traverse the filter, $T_{m}$ is the time required by the suspending medium, and $Q$ is the proportion of cells which are nonfilterable, by virtue of size, shape, or complete inflexibility. $T_{c}$ would be expected to depend, not only on plasticity of red cells, but on interactions between their surface and the surface of the channels in the filter.

In Fig. 8, the fact that more than $40 \mathrm{ml}$ of the filtrate could pass through the filter before plugging suggests that there were considerably less than $4 \times 10^{7}$ nonfilterable cells in that volume of suspension. In Fig. 9, differences between AA and CC cells were examined by use of a single 10 $\mathrm{ml}$ sample: it would appear that the first CC cells were just beginning to emerge from the filter as the final drops of suspending medium entered it. Retardation of the passage of CC cells through the filter appeared to reflect the presence of target cells, rather than hemoglobin $\mathrm{C}$ per se, for similar retardation of filtration was displayed by target cells from patients with other types of inherited and acquired hematologic disorders. Because of the lack of specificity, the cell defect responsible for decreased transport of hemoglobin C cells through membrane filters was not characterized further.

Measurements of the viscosity of packed red cells appeared to detect a more specific abnormality of CC cells. Such measurements are thought to reflect the fluidity of the interior of the cell, for suspensions of particles which have a rigid interior are much more viscous than equally concentrated suspensions of red cells $(21,22)$. Among the types of red cells which are reported to be more viscous than normal cells are HS spherocytes, cells which have been dehydrated by hypertonic solution, and sickled cells (25-27). Cellular rigidity, in these instances, is probably produced by two different mechanisms. In the first two types of cell, rigidity can be ascribed to limitation of molecular motion by overly close packing (28); in the third, it can be attributed to limitation of motion imposed by abnormal molecular interaction $(29,30)$.

The viscosity of $\mathrm{CC}$ cells was greater than that of normal cells, dehydrated normal cells or HS spherocytes, but less than that reported for sickled cells (Table VI). Differences from the normal were exaggerated when $\mathrm{MCHC}$ was raised by sus- 
pension in hypertonic solution. Analysis suggests that increased viscosity is produced by both of the mechanisms outlined above. The MCHC of CC blood is unusually high (Table I), at least as high as that reported for HS spherocytes (26), and molecular packing is at least as tight (Table VI). Abnormal molecular interactions also occur, for hemoglobin $\mathrm{C}$ forms crystals much more readily than hemoglobin A. The interactions appear to be weaker than those of hemoglobin $\mathrm{S}$ molecules, for the abnormal properties of that hemoglobin are evident in solutions containing less than $15 \mathrm{~g} /$ $100 \mathrm{ml}$, rather than the $35 \mathrm{~g} / 100 \mathrm{ml}$ required for crystal formation (31).

The MCHC at which the abnormal rigidity of $\mathrm{CC}$ cells becomes manifest is higher than that required for crystal formation in hemolysates, but lower than that required for formation of intraerythrocytic crystals. It seems likely that some "precrystalline" state of the hemoglobin in CC cells is responsible for the observed increase in their rigidity. Abnormal physical states of hemoglobin have been described in coarsely crenated normal red cells (32) and at least two other types of red cell, the deoxygenated sickle cell and the rat red cell suspended in cold citrate solution (33). The techniques used to demonstrate the latter abnormalities have been applied to $\mathrm{CC}$ cells in the present study.

Both sickled cells and paracrystalline rat cells show anomalously small changes in volume when suspended in hyper- or hypotonic solutions, as CC cells do (Fig. 13). However, decreased swelling or shrinking in all three types of cell does not necessarily reflect an altered physical state of intracellular hemoglobin. An increase in intracellular water bound to hemoglobin, a decrease in the activity of intracellular cations, or a rigid or leaky membrane could produce the same results (33), and any of these mechanisms could apply to CC cells.

Sickled cells and paracrystalline rat red cells are also birefringent, but $\mathrm{CC}$ cells are not. In the sickled cell, birefringence is thought to reflect the presence of an oriented gel, for studies of X-ray scattering and heat of compression do not yield evidence of a crystalline state $(34,35)$. On the other hand, in rat red cells, both types of study suggest a more orderly arrangement of molecules. In CC cells, absence of birefringence may have a different interpretation, for the hemoglobin crystals which form in hemolysates are also not birefringent. A possible interpretation of that finding is discussed below; studies of low-angle $\mathrm{X}$-ray scattering and heat of compression have not been carried out with CC cells.

Hemolysates prepared from sickle cells, if deoxygenated, show a sharp increase in viscosity if the hemoglobin concentration is increased above about $13 \mathrm{~g} / 100 \mathrm{ml}$ (31). The viscosity of CC hemolysates did not differ from normal hemolysates at hemoglobin concentrations below $35 \mathrm{~g} / 100$ $\mathrm{ml}$. At higher concentrations, molecular interactions in CC hemolysates became evident quite abruptly (Fig. 12): viscosity began to increase, and the hemolysates crystallized. The viscosity of AA hemolysates did not increase as abruptly and crystals did not form in these hemolysates.

In the experiments discussed above, $\mathrm{MCHC}$ was raised in vitro by suspending cells in hypertonic salt solution. Some CC cells, the microspherocytes, have high MCHC in isotonic plasma. Their viscosity is higher than that of $\mathrm{CC}$ target cells and more than twice that of normal cells. They probably contribute disproportionately to the viscosity of unfractionated CC blood and appear to be produced by an exaggeration of the normal process of cell aging. As normal red cells age, they become more dense $(13,36)$, their lipid content and volume decrease $(14,37)$, and their MCHC rises, achieving levels of $36 \mathrm{~g} / 100 \mathrm{ml}$ or higher. These changes probably occur when parts of the red cell are torn loose during turbulent blood flow (38), or during the remarkable deformations which occur in capillaries and sinuses (39-42). Fragmentation is only one of the means by which normal red cells are destroyed (43-46); under usual circumstances, the cell is removed before fragmentation proceeds to the stage of microspherocyte formation.

Under abnormal conditions, microspherocytes are seen on blood smears from persons with normal hemoglobin. The disorders in which they are seen have in common a derangement of cell membrane metabolism which may be congenital, as in hereditary spherocytosis (47), or acquired, as in autoimmune hemolytic anemia (48). The microspherocytes of CC disease are smaller and more dense than those which are produced by a primary membrane abnormality, presumably because 
the process of fragmentation is accelerated and exaggerated by the abnormal hemoglobin. Initially, one may hypothesize that cell substance is lost at the same rate as in normal cells. As MCHC rises, the limit of solubility of hemoglobin $\mathrm{C}$ is exceeded, and the cell becomes rigid. It has greater difficulty traversing the microcirculation, more membrane and water are lost, and MCHC rises further. Bits of "precrystalline" hemoglobin may act like the denatured hemoglobin within Heinz bodies, increasing the rigidity of the cell to the point that they are torn out of the cell with their associated membrane $(40,42,43,49)$.

As MCV falls and MCHC progressively increases, the cell becomes progressively more tightly packed with hemoglobin, leading to a "destructive feedback" mechanism of the type proposed by Weed and Reed (50). Microspherocytes are destroyed as they attempt to traverse the microcirculation, either by fragmentation, phagocytosis, or as a result of their increased susceptibility to osmotic lysis $(43,46)$. A few cells escape temporarily and it is within these that inclusions form as blood smears dry. After splenectomy, requirements for passage through the microcirculation become less stringent (51), and more crystals are seen on blood smears (3). As in hemoglobin $\mathrm{H}$ disease, improvement in anemia may not be striking, probably because the liver is also capable of removing microspherocytes, if they have been severely damaged.

In the preceding discussion, the central feature responsible for microspherocyte production has been considered to be comparatively increased interaction between molecules of hemoglobin $\mathrm{C}$. Hemoglobin $\mathrm{C}$ is less soluble than hemoglobin $\mathrm{A}$ at near-physiologic ionic strength, but is "salted in" with respect to hemoglobin A as ionic strength is increased. Intracellular crystallization of hemoglobin $\mathrm{C}$ is inhibited by high salt concentrations, if $\mathrm{MCHC}$ is high enough, and propane does not inhibit formation of crystals. The difference in primary structure between hemoglobin $\mathrm{A}$ and hemoglobin $C$ is substitution of lysine for glutamic acid in the sixth residue of the $\beta$-chain (52). This reversed charge appears in a region which is known to be on the extrenal surface of the molecule (30, 53). Alteration of charge, in this general area of the molecule, is known to affect crystal formation in at least one other hemoglobin: if histidine $\mathrm{CD} 3 \boldsymbol{\alpha}$ of horse hemoglobin is converted from the charged to the uncharged state by a change in $\mathrm{pH}$, the crystal habit is altered (53). Reversal of charge in hemoglobin $\mathrm{C}$ may shift the local molecular interaction from electrostatic repulsion to electrostatic attraction; the resulting change in interaction energy, at ionic strengths below 2.4 , could account for the difference in solubility. Under these conditions, increased ionic strength would be expected to increase differentially solubility of hemoglobin $\mathrm{C}$ over that of hemoglobin A by damping out the electrostatic forces. Favorable spatial arrangement of positive charges on $\beta$-chains could result in crystal formation by interacting with appropriate negative charges on the $\alpha$-chains of adjacent molecules. Short range intermolecular forces would contribute to crystallization in such a system as they do in other systems. Ponder considered intraerythrocytic inclusions of hemoglobin $\mathrm{C}$ as gels, rather than true crystals, because of their lack of birefringence (54). Actually, that observation implies only isotropy and a low order of symmetry and is entirely compatible with an arrangement of tetragonal or higher symmetry (55).

\section{Acknowledgments}

We acknowledge the helpful advice of Doctors $M$. Murayama, R. Bryan, B. Bull, and T. E. Willmarth, and Mr. U. Gessner and Miss H. Marcus; the cooperation of Brookfield Engineering Laboratories; and the skill and patience of Mr. W. Strovink, who carried out the modifications of our Brookfield LVT viscometer.

\section{References}

1. Smith, E. W., and J. R. Krevans. 1959. Clinical manifestataions of hemoglobin $\mathrm{C}$ disorders. Bull. Johns Hopkins Hosp. $104: 17$.

2. Kraus, A. P., and .L. W. Diggs. 1956. In vitro crystallization of hemoglobin occurring in citrated blood from patients with hemoglobin C. J. Lab. Clin. Med. $47: 700$.

3. Wheby, M. S., O. A. Thorup, and B. S. Leavell. 1956. Homozygous hemoglobin C disease in siblings: Further comment on intraerythrocytic crystals. Blood. $11: 266$.

4. Ager, J. A. M., and H. Lehmann. 1957. Intra-erythrocytic haemoglobin crystals. J. Clin. Pathol. 10 : 336.

5. Conley, C. L. 1964. Pathophysiological effects of some abnormal hemoglobins. Medicine, $43: 785$. 
6. Conley, C. L., and S. Charache. 1967. Mechanisms by which some abnormal hemoglobins produce clinical manifestations. Seminars Hemat. 2: 53.

7. Huisman, T. H. J., P. C. van der Schaaf, and A. van der Sar. 1955. Some characteristic properties of hemoglobin C. Blood. 10: 1079.

8. Itano, H. 1953. Solubility of naturally occurring mixtures of human hemoglobins. Arch. Biochem. Biophys. $47: 148$.

9. Jandl, J. H., R. L. Simmons, and W. B. Castle. 1961. Red cell filtration and the pathogenesis of certain hemolytic anemias. Blood. 18: 133.

10. Prothero, J. W., and A. C. Burton. 1962. The physics of blood flow in capillaries. III. The pressure required to deform erythrocytes in acid-citrate dextrose. Biophys. J. 2: 213.

11. Green, A. A. 1933. The preparation of acetate and phosphate buffer solutions of known $\mathrm{pH}$ and ionic strength. J. Am. Chem. Soc. 55: 2331.

12. Murayama, M. 1964. A molecular mechanism of sickled erythrocyte formation. Nature. 202: 258.

13. Rigas, D. A., and R. D. Koler. 1961. Ultracentrifugal fractionation of human erythrocytes on the basis of cell age. J. Lab. Clin. Med. 58: 242.

14. Westerman, M. P., L. E. Pierce, and W. N. Jensen. 1963. Erythrocyte lipids: A comparison of normal young and normal old populations. J. Lab. Clin. Med. 62: 394.

15. Oncley, J. L., G. Scatchard, and A. Brown. 1947. Physical-chemical characteristics of certain of the proteins of normal human plasma. J. Phys. Colloid Chem. $51: 184$.

16. Snedecor, G. W. 1956. Statistical methods applied to experiments in agriculture and biology. The Iowa State University Press, Ames. 394.

17.Ponder, E. 1940. The red cell as an osmometer. Cold Spring Harbor Symp. Quant. Biol. 8: 133.

18. Barcroft, J. 1928. The Respiratory Function of the Blood. Part II. Haemoglobin. Cambridge University Press, Cambridge. 2nd edition. 64.

19. Jope, H. M., and J. R. P. O’Brien. 1949. Crystallization and solubility studies on human adult and foetal haemoglobins. In Haemoglobin. F. J. W. Roughton and J. C. Kendrew, editors. Interscience, New York. 269.

20. Bessis, M., G. Nomarski, J. P. Thiéry, and J. BretonGorius. 1958. Etudes sur la falciformation des globules rouges au microscope polarisant et au microscope électronique. II. L'intérieur du globule. Comparison avec les cristaux intra-globulaires. Rev. Hématol. 13 : 249.

21. Dintenfass, L. 1962. Considerations of the internal viscosity of red cells and its effect on the viscosity of whole blood. Angiology. 13: 333 .

22. Taylor, H. M., S. Chien, M. I. Gregersen, and J. L. Lundberg. 1965. Comparison of viscometric behaviour of suspensions of polystyrene latex and human blood cells. Nature. $207: 77$.
23. Teitel, P. 1965. Disk-sphere transformation and plasticity alteration of red blood cells. Nature. 206: 409 .

24. Millipore Corporation. 1966. Catalog MF-67. 22.

25. Dintenfass, L. 1964. Rheology of packed red blood cells containing hemoglobins A-A, S-A, and S-S. J. Lab. Clin. Med. 64 : 594.

26. Erslev, A. J., and J. Atwater. 1963. Effect of mean corpuscular hemoglobin concentration on viscosity. J. Lab. Clin. Med. $62: 401$.

27. Rand, P. W., and E. Lacombe. 1964. Hemodilution, tonicity and blood viscosity. J. Clin. Invest. 43: 2214.

28. Perutz, M. F. 1948. Submicroscopic structure of the red cell. Nature. 161: 204.

29. Harris, J. W., H. H. Brewster, H. T. Ham, and W. B. Castle. 1956. Studies on the destruction of red blood cells. X. The biophysics and biology of sickle cell disease. Arch. Internal Med. 97 : 145.

30. Murayama, M. 1966. Molecular mechanism of red cell "sickling." Science. 153 : 145.

31. Allison, A. C. 1957. Properties of sickle-cell haemoglobin. Biochem. J. $65: 212$.

32. Teitel-Bernard, A. 1932. Sur quelques propriétiés physico-chimiques des hématies humaines. L'hématie muriforme. Arch. Roumaines Pathol. Exptl. Microbiol. 5 : 389.

33. Ponder, E. 1955. Red cell structure and its breakdown. In Protoplasmologia, Handbuch der Protoplasmaforschung. L. V. Heilbrunn and F. Weber, editors. Springer-Verlag, Wien, vol. 10:2.

34. Dervichian, D. G., G. Fournet, A. Guinier, and E. Ponder. 1952. Structure submicroscopique des globules rouges contenant des hémoglobines anormales. Rev. Hématol. 7 : 567.

35. Ponder, E. 1955. The specific heat and the heat of compression of human red cells, sickled red cells, and paracrystalline rat red cells. J. Gen. Physiol. 38: 575 .

36. Borun, E. R., W. G. Figueroa, and S. M. Perry. 1957. The distribution of $\mathrm{Fe}^{50}$ tagged human erythrocytes in centrifuged specimens as a function of cell age. J. Clin. Invest. 36, 676.

37. van Gastel, C., D. van den Berg, J. de Gier, and L. L. M. van Deenen. 1965. Some lipid characteristics of normal red blood cells of different age. Brit. J. Haematol. 11: 193.

38. Rous, P. 1923. Destruction of the red blood corpuscles in health and disease. Physiol. Rev. $3: 75$.

39. Guest, M. M., T. P. Bond, R. G. Cooper, and J. R. Derrick. 1963. Red blood cells: Change in shape in capillaries. Science. 142: 1319.

40. Koyama, S., S. Aoki, and K. Deguchi. 1964. Electron microscopic observations of the splenic red pulp with special reference to the pitting function. Mie Med. J. 14: 143.

41. Rifkind, R. A. 1965. Heinz body anemia: An ultrastructural study. II. Red cell sequestration and destruction. Blood, 26; 433 . 
42. Weed, R. I., and L. Weiss. 1966. The relationship of red cell fragmentation occurring within the spleen to cell destruction. Trans. Assoc. Am. Physicians. 79 : 426.

43. Rifkind, R. A. 1966. Destruction of injured red cells in vivo. Am. J. Med. $41: 711$.

44. Robertson, O. H., and P. Rous. 1917. The normal fate of erythrocytes. II. Blood destruction in plethoric animals and in animals with a simple anemia. J. Exptl. Med. 25 : 665.

45. Rous, P., and O. H. Robertson. 1917. The normal fate of erythrocytes. I. The findings in healthy animals. J. Exptl. Med. $25: 651$.

46. Weed, R. I., and C. F. Reed. 1966. Membrane alterations leading to red cell destruction. $A m$. J. Med. $41: 681$.

47. Jacob, H. S. 1966. Abnormalities in the physiology of the erythrocyte membrane in hereditary spherocytosis. Am. J. Med. $41: 734$.

48. Dacie, J. V. 1962. The Haemolytic Anaemias Congenital and Acquired. Part II. The Auto-Immune Haemolytic Anaemias. Grune and Stratton, Inc., New York. 2nd edition. 354.
49. Nathan, D. G., and R. B. Gunn. 1966. Thalassemia : The consequences of unbalanced hemoglobin synthesis. Am. J. Med. $41: 815$.

50. Weed, R. I., and C. F. Reed. 1965. The relation of erythrocyte fragmentation to cellular destruction. Blood. 26 : 894. (Abstr.)

51. Jandl, J. H., A. Richardson-Jones, and W. B. Castle. 1957. The destruction of red cells by antibodies in man. I. Observations on the sequestration and lysis of red cells altered by immune mechanisms. J. Clin. Invest. $36: 1428$.

52. Hunt, J. A., and V. M. Ingram. 1958. Allelomorphism and the chemical differences of the human haemoglobins A, S, and C. Nature. 181: 1062.

53. Perutz, M. F. 1965. Structure and function of haemoglobin. I. A tentative atomic model of horse oxyhaemoglobin. J. Mol. Biol. 13: 646.

54. Ponder, E. 1958. Globules rouges normaux, paracristallins et falciformes. Rev. Hématol. 13: 129.

55. Hartshorne, N. H., and A. Stuart. 1960. Crystals and the Polarizing Microscope. Edward Arnold, Ltd., London. 103. 